\title{
Maritime Trade and Economic Development: A Granger Causality and Bound Test Approach.
}

\author{
Richard Osadume $^{1}$ and Uzoma, C. Blessing ${ }^{1}$
}

\begin{abstract}
${ }^{1}$ Nigerian Maritime University; Dept. Marine Economics \& Finance, Nigeria; Email: richard.osadume@nmu.edu.ng,uzomahb@gmail.com
\end{abstract}

\section{Corresponding Author: Richard Osadume}

Received: 25 August 2020; Revised: 10 September 2020; Accepted: 16 September 2020; Published: 30 November 2020

\begin{abstract}
This paper investigates Maritime trade and economic development: A granger causality and Bound test approach. Most scholars believe that maritime trade openness will transform economy into a developed nation while some disagree. The main objective of this research is to examine the relationship between maritime trade and economic development; specifically, to ascertain whether maritime trade granger-causes economic development; and to determine whether there is a cointegration between maritime trade and economic development. The study used secondary data obtained from the Central Bank of Nigeria and the United Nations development Programme, and tested the effect of independent variables on a dependent variable. The variables were tested using Stationarity, heteroskedasticity, Ramsey reset, granger-causality and ARDL Bounds test at the 5\% level of significance. The findings revealed that maritime trade proxy by trade openness had a significant effect on economic development captured by HDI and the ARDL Bound test showed a significant effect of trade openness on economic development. The study concludes that maritime trade grangercauses economic development with a Bi-directional causal relationship and significant co-integration exists between them; and recommends among others the provision of conducive environment and cheap funding by the government to encourage the growth of maritime trade.
\end{abstract}

Keywords: Maritime trade, economic development, trade openness, new trade theories, less developed countries

\section{Introduction}

Emerging countries over the years have become foremost exporters and importers of goods and services, and a driving force in Maritime trade flows. Since the 1970s, the distribution of goods through the marine ways have changed significantly all over the world. These countries are no longer only sources of raw material supplies, but also key players in globalized manufacturing processes and a growing spring of demand. In terms of influence at the regional level, the Asians have continued to play a major role in cargo tonnage (loading and unloading), followed by the Americas, Europe, Oceania and Africa [1]. Nigeria is a major exporter of coffee, cocoa, rubber palm produce and crude oil and the removal of Nigeria from the West Africa trading hub will negatively affect the international maritime trading activities in West Africa [2]. Nigerian ports are developing increased capacities to handle more freight but it is sad to note that in spite of the country's huge maritime trade contributions to world GDP in monetary terms, the capacity to effectively participate in global maritime trade is seriously lacking [3]. Neoclassical trade economists such as Adams smith, David Ricardo etc. believe 
that it is only through trade openness that an economy can interact with the rest of the world and attain solid development over time. Based on this, some scholars argue in favor of a significant contribution and relationship between trade and economic growth [4-8] while others argue that trade represented by import and export trade, does not contribute significantly to economic growth $[3,9,10]$. These disagreements though in the minority, provides a challenge to be resolved convincingly. The main objective of this study is to examine the relationship between maritime trade and economic development, while the specific objectives will include: a) To ascertain whether maritime trade granger-causes economic development of Nigeria; and b) To determine whether there is a cointegrating relationship between maritime trade and economic development of Nigeria. Related research questions to support such objectives will include - Does maritime trade granger-cause the economic development of Nigeria? and, Is there a co-integration relationship between maritime trade and the economic development of Nigeria? Two basic hypotheses will stand out from such a study, which will include:

H01: Maritime trade does not granger-cause economic development of Nigeria.

H02: Maritime Trade does not exert a co-integration effect on the Economic Development of Nigeria.

The purpose of this study is to examine Maritime Trade and Economic Development in Nigeria using Granger-Causality and Bound Test approach covering 39 years, from 1980 to 2019. The study will cover; 1.0. Introduction; 2.0. Literature Review; 3.0. Materials and Methods; 4.0. Data and Analysis, and 5.0 Conclusion.

\section{Review of Related Literature}

\subsection{Concepts of Maritime Trade}

Maritime trade covers the movements of commodities through vessels between the ports of embarkation (origin), where merchandise is received/loaded from the exporter, and the port of destination where the merchandise is collected by the importer [4]. Maritime trade is commonly known as the anchor for international trade, contributing to over 80 percent of world goods trade by volume conducted on the sea. Although this is true, the actual valuation of maritime trade capacity and contribution in monetary terms is quite difficult since the figures used for estimation is usually in tons and mileage tons and this is not directly equal with any monetary-based statistics for the valuation of the world economy. Maritime Transport review, estimates merchant ships operations to contribute estimated US $\$ 380$ billion freight rates to the world economy and this translates to approximately 5 percent of total global trade [11]. With increasing world development, factors such as proximity to markets and raw materials, as well demand became the mainstream factor that, among other factors that have shaped the global economy, including major trade partners and sea routes, and has promoted a high level of inter-connectivity and interdependence.

\subsection{Genesis of Maritime Trade in Nigeria}

The genesis of Maritime trade is traceable to the advent of colonial rule on the west coast of Africa with particular reference to Nigeria from the mid-nineteenth century to 1960 when she secured her independence. The British colonial masters brought with her merchant trading to the shores of the west coast Nigeria along with attendant developments. The Nigerian situation of maritime trading is the site of the coastline on the westward part of Africa and covers approximately $850 \mathrm{~km}$ of mainly southern 
states ranging from Lagos to Ondo, Delta to Bayelsa, Rivers to Akwa Ibom and then to Cross River, surrounding the Atlantic Ocean.

The theoretical views supporting this was first mentioned by [12] in his historic work on Wealth of Nations (1776), who argued that a business operating in a country town can never achieve high levels of efficiency without a link to the outside world, that its very small sphere and market would limit its degree of specialization. Nigeria's footprint in the shipping trade commenced with the introduction of "Nigerian Line" in the mid-1950s, as a joint venture with 'Nordstrom and Company' a Finnish firm. This later metamorphosed in 1959 to the Nigerian Shipping Line Limited (NNSL) together with Palm Lines limited and Elder Dempster limited (acting as technical partners but later taken out in 1961) [12]. The shipping line operation commenced in 1980 with 2 fairly used ships but has now grown to over 122 by 2000. [13] mentioned that maritime trade constitutes approximately $95 \%$ transport mode of Nigeria's International Trade.

\subsection{Measurement of Economic Development Using the Human Development Index}

Economic Development is a more composite parameter for measuring growth and it is the increase or growth in the living standard of a country's nationale from a low income economy to a high income economy. Hence, when local quality of life is improved, there is economic development. The human development index (HDI) is used to assess the economic development of a country and it's a composite measure that takes into cognizance the health dimension, education dimension, the living standard dimension, social dimension and per capita income dimension of the population of a country. The index was developed to show that human capital and their deliverable abilities should form the basis for evaluating the development of a country and not just GDP [14]. The HDI can as well serve as a query for national policy choices and stimulate national debates on government policy priorities. It is a summary measure of average achievement in key dimensions of human development, which includes a long and healthy life, being knowledgeable and having a decent standard of living. The HDI is a composite measure for evaluating all these indices of development.

\subsection{Benefits of Maritime Trade and Economic Development of Nigeria}

Maritime trade sector provides great opportunities for global investment and in Nigeria, it has served to encourage import and export trade through providing a platform through which goods are transported by sea on a very large scale. Some of the benefits of maritime trade to Nigerian economy includes;

1. Explosive growth in trade volume and improvements in terms of trade and payments of the country.

2. Diversification of Nigeria's economy from over-dependence on crude oil exports to other lines of trade and earning massive foreign exchange in the process [15].

3. It has been a major job provider for the economy and good job prospects for dock workers, crew staff and mariners generally.

4. The Nigerian National Shipping Line (NNSL) has served as a training ground for most of the master mariners, seafarers as well as other experienced professionals in Nigeria's maritime sector. The Nigeria Maritime University in Delta state and Maritime Academy of Nigeria (MAN) in Oron (Cross River State) are case in point for manpower development in the sector.

5. Maritime trade also produces the much needed foreign exchange to the Nigerian economy. This comes in the form of collections by NIMASA of taxes and port fees, ship repairs, levies and 
charges, duty on the gross freight from any ship that calls at the Nigerian Ports for import or export reasons. These are sources of revenue to the cabotage vessel financing fund.

6. The provision of dockyard services which is expected to generate massive employment.

7. Provision of cabotage services at the various Nigerian Oil Terminals including Escravos, Bonny island and in Forcados [16].

8. Provision of security for the Nigerian territorial waters and pollution reduction through the activities of NIMASA.

\subsection{Problems Confronting Maritime Trade in Nigeria}

Some major problems facing Maritime Trade in Nigeria include - effect of political disturbances on shipping demand, Availability of merchant fleets, Transport costs, Safety and Sea security, Speed, Technology, Demographic redistribution, Globalization, Congestion and delays, Shipping Speculators, New Port reforms, New legislation on safety and environmental pollution, Transport reliability, Dispersed Manufacturing and availability of transport substitute mode.

\section{Theoretical Review}

This work adopted the New Trade Theory as its theoretical foundation, which was developed due to the limitations posed by the classical model. The new trade theory is hinged on increasing returns to specialization that arises when an industry is faced with high economies of scale [17].

The new trade theories are used to explain intra-industry trade, also known as horizontal trade or two-way trade or cross-handling-is defined as the simultaneous import and export of commodities belonging to the same industry. According to the theory, as the demand for a newly created product grows, the home country starts exporting it to other nations. Where when the demand grows, local manufacturing plants are opened to meet the request. This situation covers the whole globe time to time, thus making that product a global product.

\subsection{Empirical Reviews}

Maritime as a mode of transport has been viewed by [17] and [18], to have continued to represent the cheapest and most efficient means of moving very large volume of import and export trade goods in the Nigerian international trade. The success or failure of the Nigerian maritime sector shows a proportional impact on the economy of the sub-region [10]. In the study of foreign trade and economic development, directly proportional relationship was discovered [9], same result was corroborated in [19].

Also, Lee [5] studied the effect of trade growth on manufacturing activities using OLS statistical techniques and discovered significant effect [20,21] studied international markets and productivity using relevant economic models and discovered a positive significant effect; the study dealt with causality relationship between international trade and economic growth. Also in [6] and [22] investigated the correlation between export trade and economic growth using rank correlation and discovered a positive \& significant relationship but insignificant for relatively developed economies. [23] and [24] both argued using OLS that outward oriented developing economics achieved significant and rapid growth than inward-oriented developing ones [25] using constructed policy index analyzed economic growth rate and found a significant positive relationship between average growth and economic growth. [26] studied whether firm learn from exporting using panel data regression 
techniques for 2105 Chinese industrial enterprises and discovered a significant impact on economic. [27] Studied the relationship between international trade technology and economic growth using simple econometric analysis and found a significant effect. [28] Used institutional variables estimates to study the effect of trade on incomes. The study discovered a positive and statistically significant effect on trade on income. Also [29] in his work on international research and how development diffuses among 21 OECD countries over the period of 1971-1990, found that international trade had a significant effect on technology. In Nigeria also, most studies that focused on economic growth showed positive and significant effect while limited studies held to an insignificant effect of trade on economic growth [30,31]. Similarly, [32] in a study of the impact of international trade on Trade liberalization, Export and GDP for 70 countries discovered a positive and significant effect.

\section{Data and Methods}

The study adopted the post-facto research design approach and used secondary data obtained from central Bank of Nigeria (CBN), the National Bureau of Statistics (NBS) and the United Nations Development Programme (UNDP). The variables used in this work include; Human Development Index (HDI) proxy for measuring economic development, which serves as our dependent variable in this study, maritime trade is measured by trade openness which is import volume plus export volume as a ratio of GDP, Exchange rate and inflation.

This study is patterned after the work of [8] and [33,34] with modifications. The variables examined in this study could be represented mathematically;

$$
H D I_{t}=\alpha_{0}+a_{1} T O P t+a_{2} E X R_{t}+a_{3} I N F R_{t}+u_{t},[-]
$$

where: HDI is Human Development Index that proxy economic development [-]; TOP is Trade Openness which is export plus import as a \% of GDP [-]; EXR is Exchange Rate [-]; INF is Inflation Rate; $u_{t}$ is Error term [-]; $a_{0}-a_{1}$ is parameters.

All the incorporated variables in the modified model specified above are expected to have positive effects on the economic development. The foreign exchange rate acts as a moderating variable since it's the currency of the import and export trade transactions.

\section{Results}

We subjected the chosen variables to several diagnostic tests to ascertain the suitability and reliability of the variables in the series for use in this study and outcome discussed below;

\subsection{Diagnostic Testing}

\subsubsection{Descriptive Statistics}

Table 1 shows that the mean, median and the standard deviation reveal an even spread and variation for the series. The mean, median, maximum, minimum and the standard deviation show a positive and a healthy trend. The average kurtosis shows a platykurtic trend being in excess of 3 while the Jarque Bera probability is significant for exchange rate (0.021216) and inflation rate (0.000003) but insignificant for human development index (0.187084) and trade openness (0.423501). 
Table 1 Descriptive statistics. Source: authors

\begin{tabular}{ccccc}
\hline & EXC & HDI & INFR & TOP \\
\hline Mean & 109.9744 & 0.406368 & 19.07658 & 32.50947 \\
\hline Median & 107.0150 & 0.417500 & 12.15500 & 33.95000 \\
\hline Maximum & 361.0000 & 0.534000 & 72.84000 & 53.28000 \\
\hline Minimum & 0.673000 & 0.240000 & 5.380000 & 9.140000 \\
\hline Std. Dev. & 102.8924 & 0.100010 & 17.30123 & 12.36975 \\
\hline Skewness & 1.051379 & -0.231180 & 1.769506 & -0.393256 \\
\hline Kurtosis & 3.667362 & 1.620316 & 4.889457 & 2.316845 \\
\hline Jarque-Bera & 7.706021 & 3.352396 & 25.48320 & 1.718397 \\
\hline Probability & 0.021216 & 0.187084 & 0.000003 & 0.423501 \\
\hline Sum & 4179.026 & 15.44200 & 724.9100 & 1235.360 \\
\hline Sum Sq. Dev. & 391713.4 & 0.370071 & 11075.31 & 5661.401 \\
\hline Observations & 38 & 38 & 38 & 38 \\
\hline
\end{tabular}

\subsubsection{Tests}

The Stationarity test reveals that all the variables in the series have significant positive probabilities at the $5 \%$ level of significance $(\mathrm{HDI}=0.0017$; TOP $=0.0000 ; \mathrm{EXC}=0.0099$; and $\mathrm{INFR}=0.0002)$ and are well integrated and stationary at the first level of difference. The null hypothesis is thus rejected that there is no presence of unit root in the series.

Table 2 Stationarity test. Source: authors

\begin{tabular}{lllll}
\hline Variable & ADF Statistics & Critical value @ 5\% & Probability & Integration \\
\hline HDI & -4.9065 & -3.5331 & 0.0017 & $\mathrm{I}(1)$ \\
\hline TOP & -8.1187 & -1.9499 & 0.0000 & $\mathrm{I}(1)$ \\
\hline EXC & -4.2242 & -3.5331 & 0.0099 & $\mathrm{I}(1)$ \\
\hline INFR & -5.7591 & -3.5531 & 0.0002 & $\mathrm{I}(1)$ \\
\hline
\end{tabular}

Table 3 for heteroskedasticity test reveals that the variables in the series are insignificant having a probability of 0.4578 and 0.4434 respectively which exceed the $5 \%$ level of significance. We thus accept the null hypothesis that there is no evidence of heteroskedasticity in the variables in the series since their $\mathrm{p}$-values exceed $5 \%$ level of significance.

Table 3 Heteroskedasticity (Arch) test. Source: authors

\begin{tabular}{|c|c|c|c|}
\hline \multicolumn{4}{|c|}{ Heteroskedasticity Test: ARCH } \\
\hline F-statistic & 0.563993 & Prob. F(1,34) & 0.4578 \\
\hline Obs*R-squared & 0.587425 & Prob. Chi-Square(1) & 0.4434 \\
\hline
\end{tabular}

Table 4 shows the Ramsey reset test for the variables in the series and shows that the variables display and insignificant probability of 0.9622 at the $5 \%$ level of significance. We thus accept the Null hypothesis that the regression model adopted in this study is linear, best fit and reliable.

Table 4 Ramsey reset tests. Source: authors

\begin{tabular}{|c|c|c|c|}
\hline \multicolumn{4}{|c|}{ Ramsey RESET Test } \\
\hline \multicolumn{4}{|c|}{ Equation: UNTITLED } \\
\hline \multicolumn{4}{|c|}{ Specification: HDI HDI(-1) HDI(-2) HDI(-3) HDI(-4) TOP(1) TOP TOP(-1) } \\
\hline \multicolumn{4}{|c|}{ EXC INFR(-1) C } \\
\hline \multicolumn{4}{|c|}{ Omitted Variables: Squares of fitted values } \\
\hline & Value & df & Probability \\
\hline $\mathrm{t}$-statistic & 0.047859 & 24 & 0.9622 \\
\hline F-statistic & 0.002290 & $(1,24)$ & 0.9622 \\
\hline
\end{tabular}




\subsection{Restatement of Hypothesis}

\section{Restatement of Hypothesis One}

$\mathrm{H}_{0}$ : Maritime Trade does not granger-cause Economic Development of Nigeria

$\mathrm{H}_{1}$ : Maritime Trade granger-causes Economic Development of Nigeria

Granger-causality is a short run test and will be used to test for causality relationship between maritime trade and economic development.

Table 5 Granger-causality output. Source: authors

\begin{tabular}{lccc}
\hline Pairwise Granger Causality Tests & & & \\
\hline Date: $06 / 07 / 20 \quad$ Time: $07: 42$ & & & \\
\hline Sample: 19802019 & & & \\
\hline Lags: 2 & & & \\
\hline Null Hypothesis: & Obs & F-StatisticProb. \\
\hline HDI does not Granger Cause EXC & 38 & 1.70112 & 0.1981 \\
\hline EXC does not Granger Cause HDI & & 0.06177 & 0.9402 \\
\hline INFR does not Granger Cause EXC & 38 & 0.02632 & 0.9740 \\
\hline EXC does not Granger Cause INFR & & 1.37339 & 0.2673 \\
\hline TOP does not Granger Cause EXC & 38 & 0.80027 & 0.4577 \\
\hline EXC does not Granger Cause TOP & & 3.51204 & 0.0414 \\
\hline INFR does not Granger Cause HDI & 38 & 1.16381 & 0.3248 \\
\hline HDI does not Granger Cause INFR & & 2.84699 & 0.0723 \\
\hline TOP does not Granger Cause HDI & 38 & 0.00000 & 0.0000 \\
\hline HDI does not Granger Cause TOP & & 0.00000 & 0.0000 \\
\hline TOP does not Granger Cause INFR & 38 & 0.00000 & 0.0000 \\
\hline INFR does not Granger Cause TOP & & 0.00000 & 0.0000 \\
\hline
\end{tabular}

The output of the granger causality test reveals that exchange rate (EXC) granger-causes trade openness (TOP) in a uni-directional fashion at the $5 \%$ level of significance with a significant p-value of 0.0414, and also, human development index (HDI) granger-causes inflation rate (INFR) only at the $10 \%$ level of significance with a significant p-value of 0.0723 . We observe a strong bi-directional causal relationship between trade openness (TOP) and human development index (HDI), hence from this study, both granger-causes each other with significant p-values of 0.0000 and 0.0000 respectively. Similar explanations hold for the relationship between trade openness and inflation rate, that also show strong bi-directional causal relationships with significant p-values of 0.0000 vice-versa at the $5 \%$ level of significance. Consequently, we reject the null hypothesis to accept the alternative.

Restatement of Hypothesis Two

H0: Maritime Trade does not exert a co-integration effect on Economic Development of Nigeria

H1: Maritime Trade exerts a co-integration effect on Economic Development of Nigeria

This co-integration relationship will be tested using an autoregressive distributed lag (ARDL) Bounds Cointegration test.

The presence of long-run (co-integration) relationship was tested among the variables in the series by employing the Bound test approach. Accordingly, the results are presented in table 6 and shows that the overall computed F-statistics was greater than the F-critical values at 5\% and $10 \%$ respectively. But, the relationship between the dependent variable (HDI) and independent variable trade openness (TOP) at the 5\% level of significance is positive and significant with a p-value of 0.0461 while others remain insignificant (EXC and INFR, 0.4807 and 0.6371 respectively). Consequently, the result supports the rejection of the null hypothesis and acceptance of the alternative hypothesis; we can convincingly conclude that a long-run (Cointegration) relationship exists between trade openness (TOP) and economic development (HDI). 
Table 6 ARDL cointegration bounds test output. Source: authors

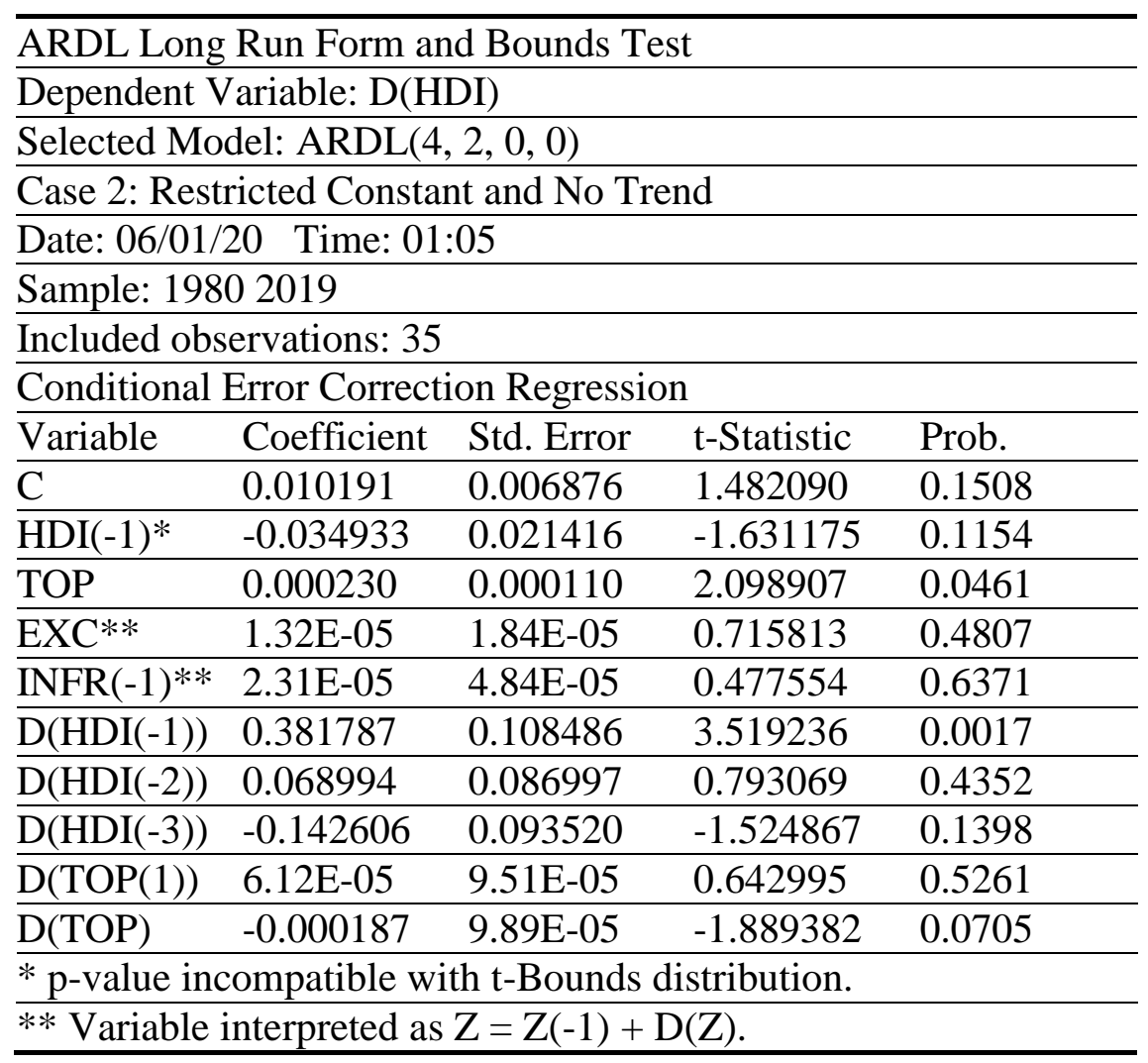

\section{Discussions}

The study investigated maritime trade and economic development of Nigeria using the grangercausality and Bounds testing statistical econometric techniques. The variables used were - human development index (HDI) as dependent variable to measure economic development; trade openness (TOP) as independent variable to measure maritime trade volumes; other moderating variables used as independent variables were inflation rate (INFR) and exchange rate (EXC). These variables in the series having been subjected to relevant diagnostics, were used to test the two hypotheses of this investigation.

The granger-causality test revealed a significant and positive bi-directional causal influence of trade openness on human development index with a p-value of 0.0000 and hence, we rejected the null hypothesis to accept the alternative, that maritime trade granger causes economic development of Nigeria. This outcome corroborates with the expectations of the literature studies [34] and also with the findings of studies that showed positive and significant outcomes [8,17-19]. The second hypothesis investigated whether a cointegration existed between maritime trade and economic development of Nigeria using ARDL Bounds testing and discovered a positive and significant effect of trade openness on human development index with a significant p-value of 0.0461 at the $5 \%$ level of significance. This result apart from conforming to the theoretical expectations of [34], it is also supported by the result of the findings of $-[31,32]$ of a positive and significant effect of trade openness on economic growth.

Plausible implications of these outcomes will include;

1. A $1 \%$ increase in trade openness will result in $0.000230 \%$ growth in economic development proxy by human development index. This means that every effort made by the federal government at growing exports will have a proportionate significant impact on foreign exchange earnings, standard of living, per capita income, and health and education standards since they are also derivable from foreign exchange growth.

2. It will lead to rapid industrialization of the domestic economy and employment boom. 


\section{Conclusion}

The results of this study shows that trade openness which proxy maritime trade had significant effect on economic development represented by human development index and the granger-causality test conducted reveal a strong Bi-directional causal relationship with p-value of 0.0000, between the two variables of interest in the short-run. Also, the study further shows that there is a cointegration (longrun) effect of trade openness on human development index using an ARDL cointegration Bounds test with a positive and significant p-value of 0.0461 . Hence, we conclude that maritime trade grangercauses economic development positively and also shows a cointegration with economic development.

Based on the foregoing, we recommend as follows;

1. The federal government should create a conducive environment for the proliferation of maritime trade in Nigeria, particularly export maritime trade. This can be achieved through providing essential ports and logistics infrastructures to support the maritime trade transportation activities e.g expanding the hinterland rivers and dredging of the canals to deepen the river depths and attract larger shipping trade vessels into the Nigerian territorial waters; also providing supportive railway facilities to convey export commodities from the farms and rural areas to the seaports for export to foreign countries.

2. The government is urged to provide adequate incentives to farmers and local manufacturers to boost their level of agricultural output and domestic industry productions as these are catalysts for export trade and overall trade openness of the country. The spillover effects of such incentives are enormous including increased GDP, employment generation, improvements in living standards, technological breakthroughs, foreign exchange growth etc. Some of these incentives would include provision of cheap funding at extremely low interest rates to boost desired sectors, improved conditionality for accessing the cabotage vessel financing funds, reduced taxations etc.

\section{Acknowledgments}

We wish to acknowledge and appreciate the management and principal officers of the Nigeria Maritime University who provided the platform for us to engage in this research work for the benefit of the academics and policy makers. We confirm that we have not received any financial support or sponsorship from any organization to carry out this research.

\section{References}

[1] United Nations Conference on Trade and Development. (2014). Review of Maritime Trade and Transport 2014 New York and Geneva: United Nations.

[2] Momoh, B. (2013). Nigerian Maritime Trade and the Demand for Transport. International Affairs and Global Strategy 15.

[3] Damachi, B.B. \& Zhaosheng, Y. 2005. The Nigeria Shipping and Indigenous Companies, Routledge: Taylor \& Francis Group 32(1).

[4] Stopford, M. (1988). Maritime Economics. 1st ed. Routledge, Taylor \& Francis Group, New York.

[5] Lee, J. (1993). International Trade, Distortions and Long-Run Economic Growth. IMF Staff Papers 40(2), 299-328.

[6] OECD (2003). Annual Report on International Trade.

[7] Wagner, J. (2007). Exports and productivity: The World Economy 30(1), 60-82.

[8] Abiodun, K. (2017). "Contribution of International Trade to Economic Growth in Nigeria" 2017 Awards for Excellence in Student Research and Creative Activity - Documents. 1. http://thekeep.eiu.edu/lib_awards_2017_docs/1

[9] Grubel, H. \& Lloyd, P.J. (1995). Intra industry trade- The Theory and measurement of International Trade in differentiated products. London and Basingstoke, The Macmillan press, 1995. 
[10] Airahuobhor, A. (2011). Controversy Trails FG Plan to Establish New Maritime Training Institutions. The Daily Independent (Lagos). Retrieved 20-03-2014.

[11] United Nations Conference on Trade and Development. (2005). Review of Maritime Transport, 2005 New York and Geneva: United Nations.

[12]Ugochukwu, E. (1990). A glance at Nigeria's maritime history. African maritime Economist 3(1), 18-29.

[13]Peretomode, V. F. (2014). The Role of the Maritime Industry and Vocational and Technical Education and Training in the Economic Development of Nigeria. A paper presentation at the NIMASA Annual conference.

[14] Adegbulu, A. (2019). Boosting African entrepreneurship with Africa continental free trade. This Day Newspapers Thursday, $25^{\mathrm{th}}$ April, 2019.

[15] Olokoba, A.O. (2006). A Review of Current Trends, Oman Medical Journal 44(7), 25-30.

[16] Igbecha, A. (2004). (as cited in importance of shipping trade in Nigeria's economy. mass global express) November 20, 2018.

[17]Ndikom, O.B. (2006). The Kernel Concept of Shipping Operations, Policies and Strategies: The industry overview. Lagos; Bunmico Publishers.

[18] Oladakun, S. (2009). Ship Building Trend. Lagos; Bunmico Publishers.

[19]Peng, S. \& Almas, H. (2010). International Trade and its Effects on Economic Growth in China. IZA Discussion Papers 5151, Institute of Labor Economics (IZA).

[20] Smith, A. (1981). An Inquiry into the Nature and Causes of the Wealth of Nations, Ch.3. Oxford University Press, London, 1981.

[21] Wagner, J. (2007). Exports and Productivity: A survey of the evidence from firm-level data. World economy 30(1), 60-82.

[22] Kavoussi, R. (1984). Export expansion and economic growth: Further empirical evidence, Journal of Development Economics, Elsevier 14(1), 241-250.

[23] Balassa, B. (1986). Economic development in small countries. Acta Oeconomica 37(3/4), 325340.

[24]Dollar, D. (1992), Outward - Oriented Developing Countries Really do Grow More Rapidly: Evidence from 95 LDCs, 1976 - 85. Economic Development and Cultural Change, 523-544.

[25] Sachs, J.D. \& Warner, A. (1995). Economic Reform and the Process of Global Integration. Brookings Papers on Economic Activity 1, 1-95.

[26] Easterly, W. \& Kraay, A. (1999). Small states, small problems? Policy Research working paper no. 2139, World Bank Washington D.C.

[27] Keller, K.L. (2001). Building customer-based brand equity. Marketing Management 10 (2), 14-19.

[28]Frankel, J.A. \& Romer, D. (1999). Does trade cause growth? American Economic Review 89, 379399.

[29]Cole, D, \& Helpman, E. (1995). International R\&D Spillovers. European Economic Review 39, 859-887.

[30] Ogborkor, C.A. (2001). Oil and Economic Growth: An Econometric Analysis. Journal of Development Alternatives and Area Studies 20(2\&3), 124-130.

[31]Egwaikhide, I. (1991): Economic Growth through Export Expansion: Evidence from Nigeria. NISAR Monograph Series No 10, NISER, Ibadan.

[32] Morgan, W., Wright, P. \& Greenway, D. (2002). Trade liberalization and growth in developing countries. Journal of Development Economics 67(1), 229-244.

[33] Barro, R.J. (1999). Inequality, Growth and investment. NBER working papers 7038, National Bureau of Economic Research, Inc.

[34] Vernon, R. (1970). The Product Life cycle Theory. [As cited in Hill, C. (2007). International Business Competing in the Global Marketplace, $6^{\text {th }}$ edition. McGraw-Hill. p.168). 